\title{
The Study on Influence Period of the Green Credit Policy Based on CGE Model
}

\author{
Zhi Yun Wang ${ }^{1, \text { a }}$, Xiong Zhong ${ }^{1, a^{*}}$ \\ ${ }^{1}$ Institute of finance, Guangzhou University, Guangdong, Guangzhou, China 510000 \\ azhongxiong1218@hotmail.com
}

Keywords: CGE model; green credit policy; period; operation performance

\begin{abstract}
To develop green credit is an indispensable important economic means for China to insist in the resource-saving and environmentally friendly green development road. The green credit policy affects the entire economic system, which can't be neglected, thus it is necessary to be concerned by all circles. Beginning with the market-oriented interest rate policy which implements punitive high interest rate in "double high" industry" in the green credit policy, the author establishes a financial Computable General Equilibrium(CGE), tries to depict the transmission route of the green credit policy, and measures systematic influences of the green policy in different periods. The results find that the green credit policy can restrain the investment behaviors of the target industry effectively and reduce output of paper-making industry and chemical industry in the short term and middle term. In the long-term period, investment and output of target industry can pick up and such a policy can restrain effects of the green credit on the output in the target industry. Therefore, it is necessary to further take feasible measures to improve effects and roles of the green credit policy.
\end{abstract}

\section{Brief Introduction}

With the constant reduction of environmental quality level in China, people pay more attention to the primary capital source of enterprises_-bank credit capital. Under the overall situation, green credit was born at the right moment. In July 2007, the former State Environmental Protection Administration(SEPA), People's Bank of China and CBRC(China Banking Regulatory Commission issued Opinions on Implementing Prevention From Credit Risks of Environmental Protection Policy, namely the green credit policy, which brings direct and indirect influences on the economic system and generate systematic influences on different periods.

\section{Construction of CGE}

There is no clear definition about the Computable General Equilibrium(CGE). Generally speaking, CGE can be described into a model that economic entity conducts digital setting. The economic entity adjusts quantity and price of commodities and elements and realizes supply-demand equilibrium confirmed by Walras's general equilibrium theory. To be simple, it is an economic model developed on the input-output model. It is a computable and disposable mathematical model and can be applied to a lot of research fields. Moreover, it can provide practical policy suggestion. The principle of the CGE means to construct several equations to describe the relationship among producers, consumers and market subjects.

Generally speaking, the modeling philosophy of CGE means to look for a group of price variables, so that economy described by the model can reach the equilibrium. Lots of Function Parameters must be demarcated when the CGE is established. The degree of coefficient precision is related to the success of the economic system stimulation directly. CGE is composed of price equation, production equation, income equation, payment equation and macroscopic closed equation, etc. The price equation of CGE is shown as follows:

$$
P_{i}^{m}=p w_{i}^{m}\left(1+t_{i}^{m}\right) R
$$




$$
\begin{gathered}
P_{i}^{e}=P W_{i}^{e}\left(1+t_{i}^{e}\right) R \\
P_{i}^{q}=\left(P_{i}^{d} D_{i}+P_{i}^{m} M_{i}\right) / Q_{i} \\
P_{i}^{x}=\left(P_{i}^{d} D_{i}+P_{i}^{e} E_{i}\right) / X_{i} \\
P_{i}^{v}=P_{i}^{x}\left(1-t_{i}^{x}\right)-\sum P_{j}^{q} a_{j i} \\
P_{i}^{k}=\sum P_{j}^{q} b_{j i}
\end{gathered}
$$

Pindex $=$ NGDP $/$ RGDP

Price equation is the definition of CGE about prices. The equation(1) indicates that domestic price $\left(P_{i}^{m}\right)$ of imported commodities means the product between international price $\left(P w_{i}^{m}\right)$ and rate(R) including import tariff( $\left.t_{i}^{m}\right)$; Equation(2) indicates that domestic price $\left(P_{i}^{e}\right)$ of export commodities means the product between international price $\left(P w_{i}^{e}\right)$ and rate(R) including export $\operatorname{subsidy}\left(t_{i}^{e}\right)$. Equation(3) and (4) define the price $\left(P_{i}^{q}\right)$ of composite commodities $\left(Q_{i}\right)$ and $\operatorname{price}\left(P_{i}^{x}\right)$ of $X_{i}$. Equation(6) defines the unit capital price $\left(P_{i}^{k}\right)$. Equation(7) defines the price index(Pindex).

\section{The Operation Mechanism of the Green Credit Policy in China}

In recent years, our commercial banks have made the obvious progress in the green credit filed. In the field of developing green economy, China not only should invest in technology, but also should support from finance, accumulate national comprehensive power to gain competitive advantages, and make national economy realize sound and sustainable development. The government should dominate establishment and perfection of relevant supporting policies for green credit and guide commercial banks to execute the green credit policy automatically and effectively under the ecological supervision mechanism. Only to let commercial banks unify economic interests with social responsibilities can it improve international competitive advantages of the green credit policy in China. For this reason, the ecological operation mechanism is constructed to analyze the green credit policy in China, assuming that the credit investment $\mathrm{x}(\mathrm{t})$ at $\mathrm{t}$ submits to the logistic growth model:

$$
\begin{aligned}
& \frac{d x}{d t}=r\left(-\frac{x}{K}\right) x \\
& x\left(t_{0}\right)=x_{0}
\end{aligned}
$$

Where $r$ is the intrinsic rate of increase in the credit market and it is the intrinsic demand of credit formed with the economic growth. $\mathrm{K}$ is the credit demand of the greatest economic development under the economic constraint condition. The equation (8) can separate variables to solve as follows:

$$
x(t)=\frac{K}{1+\left(\frac{K}{x_{0}}-1\right) e^{-r\left(t-t_{0}\right)}}
$$

Let $f(x)=r\left(1-\frac{x}{K}\right)=0$ obtain two equilibrium points as $x_{1}^{*}=0$ and $x_{2}{ }^{*}=K$, calculate $f^{\prime}(x)=r-\frac{2 r x}{K}$; because of $V f^{\prime}(0)=r>0$ and $f^{\prime}(K)=-r<0, \quad x_{1}^{*}=0$ is instable, while $x_{2}{ }^{*}=K$ is stable. When $\mathrm{x}(\mathrm{t})$ reaches the credit demand of the greatest economic development under the economic constraint condition, natural environment deteriorates and it will result in 
dissatisfaction of social residents, forming an environmental protection event. Finally, it will make banks generate bad loans.

In view of it, it is necessary to formulate certain green credit supervision policy to limit the non-environmental protection credit project and control the economic development coefficient in the intrinsic rate of increase in the credit market, showing the green economic development.

\section{The Period Analysis of the Green Credit Policy Based on CGE}

CGE constructed in the paper includes 42 production departments, current accounts, financial accounts, bank systems and financial asset accounts of institutions. There are three kinds of enterprises, including energy type, energy-intensive type and other enterprises. In the energy module, crude oil, coal and electric power are used as factor input to add into the production function, so as to stand out the role of energy investment in productive activities and realize the mutually alternative role between stimulated energy sources. The specific green credit module is shown as follows:

$$
Z D_{a}=\lambda_{a} \bullet\left(W_{c a p} \bullet W F D I S T_{\text {cap }, a} /(1+P I N F) \bullet P K_{a}\right) \varepsilon z d_{a} \bullet Q F_{c a p, a}
$$

Equation(1) shows that investment demands is determined by capital costs, investment goods price, and return on investment, namely changes of credit interest rate in banks and changes of commodity prices will affect demands of industrial investment. Assuming that commercial banks have constantly positive profit margin and it is a constant, the equation (11) is shown as follows:

$$
\sum\left(\text { INTRSTD } \text { FSTOCKD }_{\text {ins }}\right) * \operatorname{shprofitb}=\sum\left(\text { INTRSTC }_{\text {insp }} \bullet \text { FSTOCKE }_{\text {insp }}\right)
$$

With such a computational equation, it can be observed that return of investment is obtained by capital income minus interest expense. The specific equation is shown as follows:

$$
\begin{aligned}
& Y_{\text {cap }}=\sum\left(\text { WF }_{\text {cap }} \bullet \mathrm{WFDIST}_{\text {cap }, a} \bullet \mathrm{QF}_{\text {cap }}\right)+ \\
& \sum \sum\left(\text { INTRSTC }_{e} \bullet \mathrm{OMEGA1}_{e, a} \bullet \mathrm{FFLOWC}_{e}+\text { INTRSTB }_{e} \bullet \mathrm{OMEGA1}_{e, a} \bullet \mathrm{FFLOWB}_{e}\right)
\end{aligned}
$$

Capital investment in various industries covers initial capital stock and newly increased investments. Changes of investments will affect the productive activities, as shown in the Formula (13).

$$
Q F_{\text {cap }, a}=Q F 0_{\text {cap }, a}+Z D_{a}
$$

Equation (14) and equation (15) show that the rate between loans in commercial banks and direct financing is determined by the relative interest rate obtained. Interest loan of loans in commercial banks is exogenous and it is a policy variable, while interest rate of direct financing is endogenous.

$$
\begin{gathered}
\text { FFLOWC }_{e}=g 2_{e} \bullet\left(\text { FFLOWC }_{e}+\text { FFLOWB }_{e}\right) \\
g 2_{e} /\left(1-g 2_{e}\right)=\psi_{e} \bullet\left(\left(1+\text { INTRSTC }_{e}\right) /(1+\text { INTRSTA })\right) 2_{e}
\end{gathered}
$$

Data information of enterprises is combined to analyze influences of the green credit policy in four enterprises with high discharge, including paper-making industry, chemical industry, cement manufacturing and mental smelting. In the different periods of short term, middle term and long term, commercial banks' lending rate in high-discharge industry is improved by 2 percent points than other industries. Assuming that banks' profit margin is unchanged, loan interest rate in other industries is reduced corresponding, thus the green credit policy will increase the financing costs of the target industry, especially for banks' lending rate and increase of securities' interest rate. Therefore, banks' loan amount in the target industry is reduced, while securities' financing amount is increased and total financing amount is reduced. For the other industries, banks' interest rate is reduced and overall mean interest rate is decreased, thus total loan amount is increased. Bank loans 
and securities' financing amount are improved slightly. After implementing the green credit policy, from the short-term perspective, commercial banks' lending rate in the target industry is increased by $1.762 \%$ and banks' loan amount is decreased by 6.675 billion yuan. The securities' financing amount is increased by 6.155 billion yuan and overall financing amount is reduced. The securities' interest rate is increased by $0.313 \%$; mean financing costs are increased by $1.1 \%$. From the long-term perspective, financing amount of the target industrial is reduced in the direct and indirect financing market. banks' loans are reduced by 0.247 billion yuan and securities' financing is also reduced by 88 million yuan by comparing with the short term. In the long-term, the target industrial slightly increases the total financing amount by comparing with the middle term. Banks' loans and securities' financing are increased by 298 billion yuan and 22.8 million yuan, thus it can be observed that in the middle term of the green credit period, the total financial amount in the target industry is the minimum and policy influence is the greatest, followed by the middle term. On the other hand, effects of the long-term green credit policy are the weakest. Energy-intensive enterprises and other enterprises change financial costs in the short-term, middle-term and long-term, as shown in the Table 1:

Table 1. Financing Cost Changes of Different Enterprises in Different Periods(Unit: One Hundred Billion yuan)

\begin{tabular}{|c|c|c|c|c|c|c|}
\hline \multirow{2}{*}{} & \multicolumn{2}{|c|}{ Energy-intensive enterprises } & \multicolumn{3}{c|}{ Other enterprises } \\
\cline { 2 - 7 } & $\begin{array}{c}\text { Short } \\
\text { term }\end{array}$ & $\begin{array}{c}\text { Middle } \\
\text { term }\end{array}$ & $\begin{array}{c}\text { Long } \\
\text { term }\end{array}$ & $\begin{array}{c}\text { Short } \\
\text { term }\end{array}$ & $\begin{array}{c}\text { Middle } \\
\text { term }\end{array}$ & $\begin{array}{c}\text { Long } \\
\text { term }\end{array}$ \\
\hline Banks' loans & -6.675 & -6.922 & -6.624 & 4.502 & 3.971 & 5.337 \\
\hline Securities' financing & 6.155 & 5.967 & 6.195 & 0.129 & 0.078 & 0.223 \\
\hline Banks' interest rate & $1.762 \%$ & $1.762 \%$ & $1.762 \%$ & $-0.238 \%$ & $-0.238 \%$ & $-0.238 \%$ \\
\hline $\begin{array}{c}\text { Securities' interest } \\
\text { rate }\end{array}$ & $0.313 \%$ & $0.296 \%$ & $0.315 \%$ & $0.313 \%$ & $0.296 \%$ & $0.315 \%$ \\
\hline $\begin{array}{c}\text { Fair price's interest } \\
\text { rate }\end{array}$ & $1.100 \%$ & $1.092 \%$ & $1.101 \%$ & $-0.182 \%$ & $-0.183 \%$ & $-0.182 \%$ \\
\hline
\end{tabular}

With the increase of financing costs, capital pressure for enterprises' interest payment is also increased with it, so that enterprises squeeze on profit or manufacturers improve selling price. Newly increased costs are transferred to downstream firms or final consumers. Four high-discharge enterprises in the study digest some financing costs by reducing profit rate. As a result, price rising amplitude is smaller. The highest amount of increase is below $0.08 \%$. Similarly, the increase of financing costs also will affect investment activities in the target industry. The falling range in every period is between $0.05 \%$ and $0.30 \%$, indicating that the green credit policy will restrain fast growth of investments in the high-energy consumption industries and unnecessary capital is distributed to other enterprises. However, according to the output results in the industry, it can be found that short-term and middle-term green credit policy has the restraint effect on output in the paper-making industry and chemical industry, while long term is invalid, thus export of paper-making industry and chemical industry in the short term will be affected negatively. The negative effects in the middle term are not reduced, and negative effects in long term will greatly slow down. Moreover, the overall negative effects are greater than the non-metal ore and mental smelting industries.

\section{Conclusions}

To sum up, the green credit policy causes a different influence on the high-consumption industries in the short term, middle term and long term. Limited by the current industrial organizations and growth modes, yield structure adjustment in the middle term and realization 
effects of energy saving and emission reduction in the short term are not obvious. As a result, in addition to adjust investment structure positively, it is necessary to adopt green credit policies, for the sake of better serving for energy saving and emission reduction and long-term sustainable development of economy. In addition, by combining with the role of green credit in the indirect financing market, supporting policies of green securities can be applied in the direct financing market, so as to further reinforce the policy effects of the green credit.

\section{References}

[1] Chang Miao, Wang Shiwen and Li Dongwei, Implementation Foundation of Green Credit-Environmental Risk Management System in Banking Industry[J], Environmental Economy, 2008(7): 32-35;

[2] Zheng Chong, Several Reflection on Constructing Green Credit in Bank of China[J], Zhejiang Finance, 2013(1): 9-11;

[3] Wang Jianjun and Wang Tao, Equation Type Selection and Construction of CGE[J], Management Science, 2002, 15(5): 69-74;

[4] Cai Haijing, Implementation Status and Effect Inspection of the Green Credit Policy in China-Empirical Evidence Based on the Paper Making Industry, Mining Industry and Electric Power Industry[J], Finance Symposium(Journal of Zhejiang University of Finance and Economics), 2013, V170(1): 69-75;

[5] Ding Dawei, the Study on the Computed Hologram and Digital Reproduction[D], Master's Thesis of Anhui University, 2004;

[6] Chen Liming, Gui Liwei and Zhang Weiwei, Operation Mechanism and Implementation Path of the Green Credit Policy in China[J], Contemporary Economic Study, 2016(1): 91-96;

[7] Liu Jingyu and Xia Yan, etc., Short-term, Middle-term and Long-term Influence Analysis of Chinese Green Credit Policy Based on the Financial CGE[J], Chinese Management Science, 2015, 23(4): 46-52;

[8] Lv Jianglin, The Study on Pressure Test of House Pricing Reduction in Chinese Commercial Banks Based on CGE[J], Contemporary Finance, 2015(4): 43-59 